Ethos: Jurnal Penelitian dan Pengabdian kepada Masyarakat, Vol 8, No.2, Juni 2020: 212-220

\title{
IBM - Diversifikasi Produk Jagung Menjadi Produk Puding Jagung dan ICE CREAM JAGUNG
}

\author{
${ }^{1}$ Agung Prasetyo Nugroho Wicaksono, ${ }^{2}$ Aris Soelistyo \\ 1,2 Universitas Muhammadiyah Malang, Malang, Jawa Timur, Indonesia \\ email: Iagungpnw@umm.ac.id, ${ }^{2}$ aris_s@umm.ac.id
}

\begin{abstract}
Food Commodity and its diversification with the basic ingredients made from corn, a number of corn-based processed food products as a manifestation of food diversification which certainly has a high nutritional content so that it can be an economically valuable food reinforcement product to increase the income of rural communities by making independent economic entrepreneurs. in Latsari Village, Mojowarno District, Jombang Regency is important and strategic to be given knowledge about corn processed food products which on one side is a creation of a type of side and side food that can be used as a source of income-generating business. This Community Service activity is aimed at providing hands-on training in various types of manufacturing of Corn-based processed food products made into corn pudding and Corn Ice Cream. The output of this activity is in the form of SOP for making Corn Pudding and Corn Ice Cream. The dedication method is carried out with a counseling approach and direct practice in the field.
\end{abstract}

Keywords: Corn, Corn pudding, Corn Ice Cream

\begin{abstract}
Abstrak. Komodite pangan dan diversifikasinya dengan bahan dasar pembuatannya dari Jagung, sejumlah produk pangan olahan berbasis jagung sebagai wujud dari diversifikasi pangan yang tentunya memiliki kandungan gizi yang tinggi sehingga dapat menjadi produk penguatan pangan yang bernilai ekonomis untuk peningkatan pendapatan masyarakat pedesaan dengan menjadikan wirausaha ekonomi mandiri. di Desa Latsari, Kecamatan Mojowarno, Kabupaten Jombang menjadi penting dan strategis untuk diberikan pengetahuan tentang produk pangan olahan Jagung yang disatu sisi sebagai kreasi jenis pangan bergisi dan disisi yang dapat digunakan sebagai sumber usaha yang menghasilkan pendapatan. Kegiatan Pengabdian ini ditujukan untuk memberikan pelatihan praktik langsung berbagai jenis pembuatan produk makan olahan berbasis Jagung dibuat menjadi pudding jagung dan Ice Cream Jagung. Luaran dari kegiatan ini berupa SOP pembuatan Puding jagung dan Ice Cream Jagung. Metode pengabdian dilakukan dengan pendekatan penyuluhan dan praktek langsung di lapangan.
\end{abstract}

Kata Kunci: Jagung, Puding Jagung, Ice Cream Jagung

\section{Pendahuluan}

\section{Analisis Situasi}

Kabupaten Jombang yang
didominasi oleh penggunaan lahan
pertanian sebesar 103.344 hektar atau
sekitar 86,54\% dari total luas
penggunaan lahan, memiliki potensi
pertanian yang cukup strategis.
Berdasarkan data dari tahun 2012 sampai
dengan 2017, pertumbuhan produksi

jagung memiliki trend yang meningkat dari tahun ke tahun, sehingga komoditas jagung masih memiliki peluang yang sangat besar untuk dikembangkan menjadi produk olahan lainya (Fitrianingrum et al., 2018). Namun kondisi pengolahan jagung di kabupaten jombang belum maksimal. Kondisi saat ini di kabupaten Jombang hanya terdapat satu industri besar dan satu industri sedang yang berada di kecamatan Mojoagung dan di kecamatan Ngoro. 
Pada umumnya para petani biasanya menjual produksi jagung ke luar kota dalam bentuk jagung tanpa diolah. Hal itu tentunya dikarenakan minimnya informasi atau pengetahuan tentang bagaimana mengolah jagung menjadi produk olahan jagung lainya yang lebih bernilai ekonomi. Maka pengabdian ini bertujuan untuk memberikan stimulasi kepada masyarakat di sekitar lokasi produksi jagung agar masyarakat dapat mengolah produk jagung yang sudah ada menjadi produk olahan jagung lainya.

Jagung merupakan salah satu tanaman yang penting sebagai sumber karbohidrat lain yang digunakan untuk memenuhi kebutuhan gizi. Oleh karena itu, jagung berpotensi sebagai bahan pangan alternatif pengganti atau subtitusi beras. Selain itu jagung mengandung lemak, protein, mineral dan vitamin. Berikut adalah kandungan zat gizi jagung menurut penelitian yang telah dilakukan sebelumnya (Suarni et al., 2019), adalah:

\section{Tabel 1}

Kandungan Zat Gizi Pada Jagung

\begin{tabular}{|c|c|c|c|}
\hline \multirow{2}{*}{ Kandungan } & \multicolumn{3}{|c|}{ Satuan / 100 gram Bahan } \\
\cline { 2 - 4 } & $\begin{array}{c}\text { Jagung } \\
\text { Manis }\end{array}$ & $\begin{array}{c}\text { Jagung } \\
\text { Biasa }\end{array}$ & Satuan \\
\hline Energi & 96.00 & 129.00 & Cal \\
\hline Protein & 3.50 & 4.10 & Gram \\
\hline Lemak & 1.00 & 1.30 & Gram \\
\hline Karbohidrat & 22.80 & 30.30 & Gram \\
\hline Kalsium & 3.00 & 5.00 & $\mathrm{mg}$ \\
\hline Fosfor & 111.00 & 108.00 & $\mathrm{mg}$ \\
\hline Besi & 0.70 & 1.10 & $\mathrm{mg}$ \\
\hline Vitamin a & 400.00 & 117.00 & $\mathrm{SI}$ \\
\hline Vitamin b & 0.15 & 0.18 & $\mathrm{mg}$ \\
\hline Vitamin c & 12.00 & 9.00 & $\mathrm{mg}$ \\
\hline Air & 72.70 & 63.50 & $\mathrm{Gram}$ \\
\hline
\end{tabular}

Sumber : Data Diolah, 2019 (Suarni et al., 2019)

Menurut studi yang dilakukan di

Cornell University, jagung merupakan salah satu anti oksidan yang dapat melawan radikal bebas yang dapat menyebabkan munculnya penyakit kanker (Krisnamurthi, 2010). Berdasarkan ulasan-ulasan sebelumnya, jagung memiliki manfaat yang sangat berguna untuk pemenuhan nutrisi yang cukup bagi tubuh.

\section{Permasalahan Mitra}

Berdasarkan survey awal pengabdian menunjukan sejumlah fenomena yang ditemukan di Desa Latsari, Kecamatan Mojowarno, Kabupaten Jombang. Secara rerata kehidupan mitra banyak tergantung pada sector pertanian pangan dengan kondisi harga yang tidak menentu, sering berfluktuasi bahkan menurun saat panen tiba, sehingga para petani dihadapkan pada kondisi kerugian atau tidak mencapai titik impas. Selain itu, pada sector pertanian ditandai dengan lag waktu antara masa tanam dan masa panen dan produk pertanian disifati perishable good atau cepat membusuk. Oleh karena, itu perlu disuguhkan penyimpanan yang strategis, serta permasalahan pemasaran dan penyimpanan hasil panen, dimana Bulog belum berperan aktif bahkan tidak ada. Sejumlah petani yang menanam jagung selain padi sebagai produk pangan utama, diversifikasi tanaman pangan juga dilakukan. Subtitusi antara padi dan jagung sebagai produk pangan sering terjadi, namun dalam perkembangannya hubungan diantara keduanya sudah bergeser menuju hubungan saling melengkapi satu dengan lainnya, sehingga potensi nilai gizi dan nilai tambah peningkatan pendapatan terjadi.

Minimnya pengetahuan perihal pengolahan produk pangan olahan jagung yang ada pada masyarakat di Desa Latsari, Kecamatan Mojowarno, Kabupaten Jombang, dimana hasil panen jagung yang selama ini hanya dimanfaatkan untuk makanan ternak, karena harga jual relative rendah pada 
saat panen yang berbeda dengan waktu diluar panen. Oleh karena itu, menjadi penting dan strategis penguatan pemahaman petani jagung untuk dapat melakukan diversifikasi pengolahan aneka ragam pangan yang berbasis "jagung" yang disesuaikan dengan kondisi pedesaan dan suasana lingkungan.

Hasil panen jagung sebahagian besar dipasarkan pada pasar desa dalam bentuk asli (belum terproses lebih lanjut) dengan harga yang relative murah. Disisi lain, konsumsi jagung olahan hanya dalam bentuk makanan pelengkap bergedel jagung. Bahkan, pemasaran hasil panen dalam bentuk jagung kurang optimal dan perlu dilakukan pengolahan lebih lanjut untuk menghasilkan nilai tambah yang lebih tinggi. Namun sejumlah permasalahan berkaitan masih minimnya pengetahuan berkaitan dengan diversifikasi pengolahan pangan berbasis jagung. Selain itu produk jagung diharapkan menjadi produk unggulan desa yang bernilai gizi.

\section{Permasalahan Isu-Isu Strategis}

Berdasarkan evaluasi diri yang berkaitan dengan pengembangan produk pangan olahan jagung menjadi produk pangan unggulan, tentunya berkait dengan dinamisasi perkembangan teknologi pangan dan digital marketing serta perkembangan keuangan micro, namun semuanya masih belum sepenuhnya masuk pada pedesaan. Permasalahan tersebut dapat dikelompokkan kedalam tiga kelompok akar permasalahan, yaitu permasalahan kualitas produk pangan dan proses pengolahan pangan yang perlu dikuatkan konsistensi, keajegan, dinamisasi dari waktu ke waktu, oleh karena itu kebaharuan harus diprioritaskan dengan mengembangkan sejumlah research dan pengabdian yang mengedepankan perkembangan pengolahan produk pangan yang berkembang yang seiring dengan perkembangan prilaku manusia dalam lingkup uncertainty dan ekspektasi rasional serta spekulasi, kurangnya inovasi pendidikan pengolahaan pangan serta teknologi pasca panen untuk petani. Kemudian masih belum optimalnya peran desa dan Bulog dalam menangani produk petani saat panen, dimana harga produk petani saat panen yang rendah karena tidak adanya bulog, khususnya Jagung yang harganya anjlok saat panen. Disisi lain, pemasaran jagung hanya ditujukan untuk pakan ternak, padahal kandungan Gizi untuk produk Jagung sangat tinggi dan strategis untuk pemenuhan gizi masyarakat pedesaan, dikuatkan lagi bilamana produk pangan tersebut dapat ditransformasi bentuknya menjadi pangan olahan, misalnya dari jagung menjadi Puding dan Ice Cream Jagung yang tentunya akan bernilai gizi tinggi serta menjadi sumber wirausaha baru yang menjanjikan dan menaikan nilai pendapatan masyarakat.

Ringkasan masalah dan akar permasalahan tertera pada tabel 2 dibawah ini : 


\section{Masalah Dan Akar Permasalahan Masyarakat Di Desa Latsari,}

\section{Kecamatan Mojowarno, Kabupaten Jombang}

\begin{tabular}{|c|c|c|c|c|c|c|c|c|}
\hline \multicolumn{2}{|r|}{ Permasalahan } & \multirow[t]{2}{*}{ Akar Permasalahan } & \multicolumn{6}{|c|}{ Isu-Isu Strategis } \\
\hline No & Keterangan & & $\mathbf{L}$ & $\mathbf{R}$ & $\mathbf{A}$ & I & $\mathbf{S}$ & $\mathbf{E}$ \\
\hline 1 & 2 & 3 & 4 & 5 & 6 & 7 & 8 & 9 \\
\hline 1. & $\begin{array}{l}\text { Tingginya waktu senggang petani } \\
\text { antara tanam dan waktu panen }\end{array}$ & $\begin{array}{l}\text { Kurang kuatnya penguasaan } \\
\text { atau pemahaman ilmu }\end{array}$ & $\mathbf{x}$ & $\mathbf{x}$ & $\mathbf{x}$ & $\mathbf{x}$ & $\mathbf{x}$ & $\mathbf{x}$ \\
\hline 2. & $\begin{array}{l}\text { Lemahnya perhatian kelembagaan } \\
\text { desa untuk pengembangan produk } \\
\text { pangan jagung olahan sebagai Produk } \\
\text { Unggulan Olahan Pangan } \\
\text { Pedesaanyang strategis }\end{array}$ & $\begin{array}{l}\text { pengolahan pangan, khususnya } \\
\text { pengolahan pangan berbasis } \\
\text { produk Jagung }\end{array}$ & $\mathbf{x}$ & $\mathbf{x}$ & $\mathbf{x}$ & $\mathbf{x}$ & $\mathbf{x}$ & \\
\hline 3. & $\begin{array}{l}\text { Minimnya pengetahuan petani untuk } \\
\text { diversifikasi pangan, dan keaneka } \\
\text { ragaman produk pangan }\end{array}$ & & $\mathbf{x}$ & $\mathbf{x}$ & $\mathbf{x}$ & $\mathbf{x}$ & $\mathbf{x}$ & $\mathbf{x}$ \\
\hline 4. & $\begin{array}{l}\text { Minimnya Pengetahuan Kadar Gizi } \\
\text { produk olahan pangan jagung dan } \\
\text { lemahnya kesadaran untuk } \\
\text { menaikkan nilai tambah ekonomi } \\
\text { bagi masyarakat desa }\end{array}$ & $\begin{array}{l}\text { Kurangnya inovasi rekayasa } \\
\text { pangan yang bergizi dan } \\
\text { menguatkan-nya nilai tambah } \\
\text { pendapatan masyarakat desa }\end{array}$ & $\mathbf{x}$ & $\mathbf{x}$ & $\mathbf{x}$ & $\mathbf{x}$ & $\mathbf{x}$ & $\mathbf{x}$ \\
\hline
\end{tabular}

Berdasarkan fenomena/gejala dan akar permasalahan yang ditemukan dengan mengacu pada data yang dikumpulkan, maka diajukan beberapa alternatif strategi penyelesaian masalah seperti tertera pada tabel 3 sebagai berikut:

\section{Tabel 3}

\section{Strategi Yang Akan Dilakukan Untuk Mengatasi Akar Permasalahan Yang} Berhasil Diidentifikasi

\begin{tabular}{|c|c|c|c|}
\hline \multicolumn{2}{|r|}{ Gejala/Fenomena Masalah } & \multirow[t]{2}{*}{ Akar Permasalahan } & \multirow{2}{*}{$\begin{array}{c}\text { Strategi Pelaksanaan Kegiatan } \\
\text { Yang Akan Dilakukan }\end{array}$} \\
\hline No & Keterangan & & \\
\hline 1. & $\begin{array}{l}\text { Tingginya waktu senggang petani } \\
\text { antara tanam dan waktu panen }\end{array}$ & \multirow{3}{*}{$\begin{array}{lr}\text { Kurang } & \text { kuatnya } \\
\text { penguasaan } & \text { atau } \\
\text { pemahaman } & \text { ilmu } \\
\text { pengolahan } & \text { pangan, } \\
\text { khususnya pengolahan } \\
\text { pangan } \quad \text { berbasis } \\
\text { produk Jagung }\end{array}$} & \multirow{3}{*}{$\begin{array}{l}\text { Peningkatan Penguatan Keilmuan } \\
\text { masyarkat desa terhadap } \\
\text { pengolahan produk pangan Jagung }\end{array}$} \\
\hline 2. & $\begin{array}{l}\text { Lemahnya perhatian kelembagaan } \\
\text { desa untuk pengembangan produk } \\
\text { pangan jagung olahan sebagai } \\
\text { produk unggulan olahan pangan } \\
\text { pedesaan yang strategis }\end{array}$ & & \\
\hline 3 & $\begin{array}{l}\text { Minimnya pengetahuan petani } \\
\text { untuk diversifikasi pangan, dan } \\
\text { keaneka ragaman produk pangan }\end{array}$ & & \\
\hline 4. & $\begin{array}{l}\text { Minimnya Pengetahuan Kadar Gizi } \\
\text { produk olahan pangan jagung dan } \\
\text { lemahnya kesadaran untuk } \\
\text { menaikkan nilai tambah ekonomi } \\
\text { bagi masyarakat desa }\end{array}$ & $\begin{array}{l}\text { Kurangnya inovasi } \\
\text { rekayasa pangan yang } \\
\text { bergizi dan } \\
\text { menguatkan-nya nilai } \\
\text { tambah pendapatan } \\
\text { masyarakat desa }\end{array}$ & $\begin{array}{l}\text { Perlunya rekayasa produk pangan } \\
\text { jagung menjadi produk puding } \\
\text { Jagung dan Ice Cream Jagung }\end{array}$ \\
\hline
\end{tabular}


Secara spesifik telah diprioritaskan beberapa permasalahan yang akan dipecahkan bersama. Metode yang digunakan dalam pemecahan masalah ini dilakukan secara parsitipatif, tutorial, pendampingan, pelatihan dan demplot dilokasi Kelompok Mitra. Permasalah mitra dan solusinya secara spesifik disajikan pada tabel 4 , dibawah ini:

\section{Tabel 4}

\begin{tabular}{|c|c|}
\hline \multicolumn{2}{|c|}{$\begin{array}{c}\text { Beberapa Permasalahan Mitra } \\
\text { Dalam Kenekaragaman Produksi } \\
\text { Pangan Olahan Jagung }\end{array}$} \\
\hline Problem mitra & Solusi \\
\hline $\begin{array}{l}\text { 1. } \\
\text { keterbatasan } \\
\text { pengetahuan Mitra } \\
\text { dalam pengolahan } \\
\text { diversifikasi } \\
\text { pangan berbasis } \\
\text { jagung }\end{array}$ & $\begin{array}{l}\text { Pemberi sejumlah } \\
\text { pelatihan /praktek } \\
\text { langsung } \\
\text { pembuatan produk } \\
\text { pangan }\end{array}$ \\
\hline $\begin{array}{l}\text { Belum mengetahui } \\
\text { nilai kandungan } \\
\text { gizi dari produk } \\
\text { pangan berbasis } \\
\text { jagung }\end{array}$ & $\begin{array}{l}\text { Perlu pengetahuan } \\
\text { untuk dapat } \\
\text { menilai berapa } \\
\text { nilai gizi setiap } \\
\text { produk pangan } \\
\text { yang dibuat atau } \\
\text { diproduksi } \\
\text { berbasis jagung }\end{array}$ \\
\hline 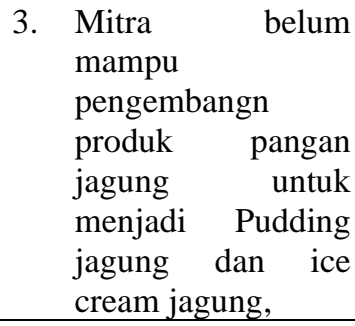 & $\begin{array}{l}\text { Dilakukan } \\
\text { penyuluhan } \\
\text { praktek langsung } \\
\text { ke lapangan }\end{array}$ \\
\hline $\begin{array}{llr}\text { 4. } & \text { Mitra belum } \\
\text { menguasahi } & \text { teknik } \\
\text { pembuatan pudding } \\
\text { dan Ice Cream } \\
\text { jagung }\end{array}$ & $\begin{array}{l}\text { Pelatihan dan } \\
\text { praktik langsung } \\
\text { pembuatan produk }\end{array}$ \\
\hline $\begin{array}{llr}\text { 5. } & \text { Mitra } & \text { belum } \\
\text { mengetahui metode } & \\
\text { pemasaran } & \text { produk } \\
\text { pangan } & \text { olahan } \\
\text { jagung } & \\
\end{array}$ & $\begin{array}{l}\text { Dilakukan } \\
\text { simulasi / estimasi } \\
\text { pemasaran produk }\end{array}$ \\
\hline $\begin{array}{l}\text { 6. Membangun } \\
\text { kemandirian } \\
\text { dengan } \\
\text { berwirausaha }\end{array}$ & $\begin{array}{l}\text { Pembinaan untuk } \\
\text { membangun wira } \\
\text { usaha mandiri }\end{array}$ \\
\hline
\end{tabular}

Hasil kesepakatan antara mitra dengan team pengabdi menghasilkan titik temu permasalahan yang diselesaikan untuk penyesuaian antara keingingan pengabdi dengan mitra sehingga dicapai optimalitas. Khususnya berkaitan aspek produksi olahan jagung menjadi Ice Cream dan Pudding Jagung.

\section{Metode}

Pada tahap ini dijabarkan materi dan metode pelaksanaan yang digunakan untuk menyelesaikan permasalahan pengabdian. Materi dan metode pelaksanaan secara umum akan menjabarkan tentang kerangka pemecahan masalah, realisasi pemecahan masalah, khalayak sasaran, metode kegiatan yang digunakan, monitoring dan evaluasi. Adapun metode pelaksanaan kegiatan dilakukan dengan berbagai aktifitas dimana aktifitas pengabdian, metode kegiatan, indikator capaian serta variabel yang ingin dicapai disajikan sebagai berikut:

Tahap I. Tinjauan survey awal atau penjajagan pada mitra berkait potensi dan permasalahan mitra untuk dapat dicarikan penyelesaian terbaik, dimana mitra terpilih adalah petani dan ibu rumah tangga, petani dengan tanaman yang ditanam adalah jagung dengan metode pemasaran dalam bentuk mentahan. Oleh karena itu, penyuluhan awal pada mitra berkait nilai gizi dari jagung yang sangat potensial dan beberapa alternative pengolahan pangan yang dapat digunakan sebagai sajian divesifikasi pangan keluarga, pada giliran berikutnya dapat dimanfaatkan untuk lahan bisnis (wirausaha) yang menjanjikan nilai tambah penghasilan bagi keluarga.

Tahap II. Pelatihan /praktek langsung pembuatan produk pangan olahan berbasis jagung. Praktek pembuatan berbagai produk pangan olahan diantaranya (1) pembuatan Puding Jagung dan (2) Pembuatan Ice Cream Jagung 
Tahap III. Penyuluhan berkait dengan upaya upaya optimalisasi pemasaran produk pangan olahan jagung, sehingga dapat meningkatkann nilai tambah penghasilan keluarga.

Tabel 5

Tema,Variabel, Indikator dan target Khalayak Sasaran

\begin{tabular}{|c|c|c|c|c|c|}
\hline Tema & Variabel & $\begin{array}{c}\text { Indikator yang } \\
\text { dipetakan/produk } \\
\text { yang di hasilkan }\end{array}$ & $\begin{array}{c}\text { Khalayak } \\
\text { sasaran }\end{array}$ & $\begin{array}{c}\text { Target } \\
\text { Khalayak } \\
\text { Sasaran }\end{array}$ & $\begin{array}{c}\text { Waktu } \\
\text { Pelaksanaan }\end{array}$ \\
\hline \multirow{5}{*}{ 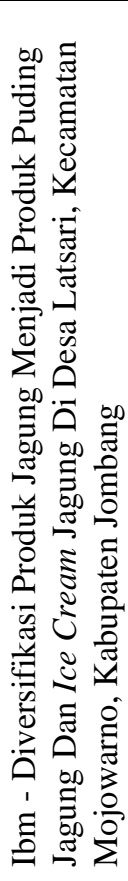 } & Penyuluhan & $\begin{array}{l}\text { Frekwensi } \\
\text { penyuluhan yang } \\
\text { dilakukan }\end{array}$ & $\begin{array}{l}\text { Mitra } \\
\text { masyarakat } \\
\text { desa }\end{array}$ & $\begin{array}{l}80 \% \text { dari } \\
\text { sampel }\end{array}$ & \multirow{5}{*}{$\begin{array}{l}\text { Sejak } \\
\text { pengabdian di } \\
\text { setujui } \\
\text { pendanaannya }\end{array}$} \\
\hline & $\begin{array}{l}\text { Pemilihan } \\
\text { Random }\end{array}$ & $\begin{array}{l}\text { purposive random } \\
\text { sampling, dipilih } 2 \\
\text { warga dusun sebagai } \\
\text { sampel }\end{array}$ & $\begin{array}{l}\text { Mitra } \\
\text { masyarakat } \\
\text { desa }\end{array}$ & $\begin{array}{l}90 \% \text { dari } \\
\text { sampel }\end{array}$ & \\
\hline & $\begin{array}{l}\text { Pemilihan } \\
\text { Bahan untuk } \\
\text { Proses } \\
\text { Produksi } \\
\text { puding } \\
\text { Jagung }\end{array}$ & $\begin{array}{l}\text { Dihasilkan komposisi } \\
\text { yang tepat untuk } \\
\text { produksi Puding } \\
\text { jagung }\end{array}$ & $\begin{array}{l}\text { Mitra } \\
\text { masyarakat } \\
\text { desa }\end{array}$ & $\begin{array}{l}90 \% \text { dari } \\
\text { sampel bisa } \\
\text { membuat } \\
\text { produk olahan } \\
\text { jagung }\end{array}$ & \\
\hline & $\begin{array}{l}\text { Dimensi } \\
\text { Produksi Ice } \\
\text { Cream } \\
\text { Jagung }\end{array}$ & $\begin{array}{l}\text { Besaran jumlah } \\
\text { produksi yang akan } \\
\text { dihasilkan setiap kali } \\
\text { proses produksi }\end{array}$ & $\begin{array}{l}\text { Mitra } \\
\text { masyarakat } \\
\text { desa }\end{array}$ & $\begin{array}{l}50 \% \text { dari } \\
\text { sampel dpt } \\
\text { berproduksi }\end{array}$ & \\
\hline & $\begin{array}{l}\text { Dimensi } \\
\text { Pemasaran } \\
\text { hasil }\end{array}$ & $\begin{array}{l}\text { Model pemasaran } \\
\text { yang dilakukan } \\
\text { (dalam bentuk } \\
\text { bungkusan dan } \\
\text { plastik) }\end{array}$ & $\begin{array}{l}\text { Mitra } \\
\text { masyarakat } \\
\text { desa }\end{array}$ & $\begin{array}{l}50 \% \text { dari } \\
\text { sampel dapat } \\
\text { memasarkan }\end{array}$ & \\
\hline
\end{tabular}

Adapun rangkaian tahapan tersebut serta indicator capaian yang diharapkan dan variable target yang ingin dicapai disajikan pada tabel 6 dibawah ini:

\section{Tabel 6}

\section{Metode Kegiatan dan Indikator Capaian}

\begin{tabular}{|l|l|l|l|}
\hline $\begin{array}{l}\text { Aktifitas } \\
\text { Pengabdian }\end{array}$ & Metode Kegiatan & Indikator Capaian & Variabel \\
\hline Penyuluhan & $\begin{array}{l}\text { Diskusi dan program } \\
\text { penyuluhan langsung }\end{array}$ & $\begin{array}{l}\text { Besaran frekwensi } \\
\text { penyuluhan yang } \\
\text { dilakukan per bulan }\end{array}$ & $\begin{array}{l}\text { Jumlah yang dilakukan } \\
\text { yaluhan }\end{array}$ \\
\hline $\begin{array}{l}\text { Dimensi Produksi } \\
\text { produk }\end{array}$ & $\begin{array}{l}\text { Praktek Langsung } \\
\text { melalui pemilihan bahan } \\
\text { yang dibutuhkan }\end{array}$ & $\begin{array}{l}\text { Dihasilkan komposisi } \\
\text { standar pembuatan } \\
\text { produk }\end{array}$ & $\begin{array}{l}\text { Jumlah produk yang } \\
\text { dihasilkan setiap satu } \\
\text { proses produksi }\end{array}$ \\
\hline $\begin{array}{l}\text { Dimensi } \\
\text { Pemasaran } \\
\text { Produksi produk }\end{array}$ & $\begin{array}{l}\text { Demonstrasi dan } \\
\text { penyuluhan }\end{array}$ & $\begin{array}{l}\text { Jenis /model pemasaran } \\
\text { yang dikembangkan }\end{array}$ & $\begin{array}{l}\text { Model pemasaran atas } \\
\text { produk yang dihasilkan }\end{array}$ \\
\hline
\end{tabular}

Metode yang digunakan dalam pemecahan masalah ini dilakukan secara parsitipatif, tutorial, pendampingan, pelatihan dan demplot dilokasi Kelompok Mitra. Materi dan teknologi 
yang ditawarkan dalam penyelesaiaan masalah diringkas sebagai berikut :

1. Pelatihan dan demoplot SPO Metode Pembuatan Puding jagung.

2. Pelatihan dan demoplot SPO Metode pembuatan Ice Cream Jagung.

3. Melakukan kegiatan pendampingan, monitoring dan evaluasi untuk keberhasilan dan keberlanjutan program.

\section{Hasil dan Pembahasan}

Kegiatan pengabdian dilakukan pada tanggal 29 Agustus 2019 yang berlokasi pada mitra yang beralamatkan Dusun Kedungpring, RT 1 / RW 1 Desa Latsari, Kecamatan Mojowarno, Kabupaten Jombang. Tabel 7 merupakan hasil dari monitoring kegiatan pengabdian:

Tabel 7

Evaluasi dan Monitoring Kegiatan Pengabdian

\begin{tabular}{|c|c|c|c|}
\hline No. & Kriteria & Indikator pencapaian & Hasil Capaian \\
\hline 1 & Penyuluhan & $\begin{array}{l}\text { Besaran frekwensi penyuluhan } \\
\text { yang dilakukan }\end{array}$ & $\begin{array}{l}\text { Penyuluhan yang } \\
\text { dilakukan satu kali }\end{array}$ \\
\hline 2 & $\begin{array}{l}\text { Dimensi } \\
\text { Produksi Puding } \\
\text { jagung dan ice } \\
\text { cream jagung }\end{array}$ & $\begin{array}{l}\text { Dihasilkan komposisi standar } \\
\text { pembuatan Puding jagung dan } \\
\text { ice cream jagung dalam satu kali } \\
\text { proses produksi. Berikut adalah } \\
\text { komposisi bahan yang } \\
\text { diperlukan : } \\
\text { Produk pudding jagung } \\
\text { Jagung } 500 \text { gr } \\
\text { Air } 200 \text { ml } \\
1 \text { Agar-agar putih / bening } \\
\text { (swallow tidak berwarna) } \\
50 \text { ml Susu kental manis } \\
150 \text { ml Santan } \\
100 \text { gr Gula pasir } \\
\text { Produk ice cream jagung } \\
2 \text { Jagung } \\
100 \text { - } 150 \text { ml Susu cair / UHT } \\
1 \text { Telur } \\
5 \text { sendok makan whipping cream } \\
\text { Gula pasir } \\
\text { Air es } 100 \text { ml } \\
\text { Kemudian melakukan tahapan } \\
\text { proses produksi adalah sebagai } \\
\text { berikut : } \\
\text { Produk pudding jagung } \\
\text { Jagung yang sudah disisir } \\
\text { matang bersama dengan susu cair } \\
\text { diblender sampai halus, } \\
\text { kemudian disaring. } \\
\text { Selanjutnya kocok telur pada } \\
\text { tempal lain. }\end{array}$ & $\begin{array}{l}\text { Jumlah output yang } \\
\text { dihasilkan setiap satu } \\
\text { proses produksi adalah } \\
7 \text { unit dari masing - } \\
\text { masing produk }\end{array}$ \\
\hline
\end{tabular}




\begin{tabular}{|c|c|c|c|}
\hline No. & Kriteria & Indikator pencapaian & Hasil Capaian \\
\hline & & $\begin{array}{l}\text { Masukan adonan jagung lalu } \\
\text { masak diatas api sedang dengan } \\
\text { pengadukan yang merata hingga } \\
\text { telur terasa matang, lalu tiriskan. } \\
\text { Pada tempat yang berbeda } \\
\text { masukan whipping cream, gula } \\
\text { pasir dan air es sampai } \\
\text { mengembang kaku. } \\
\text { Kemudian campurkan bahan } \\
\text { jagung, aduk hingga merata } \\
\text { dengan menggunakan spatula. } \\
\text { Masukkan ke dalam wadah yang } \\
\text { kedap udara atau tertutup rapat. } \\
\text { Simpan pada freezer selama } 4 \\
\text { jam atau lebih hingga membeku } \\
\text { menjadi ice cream jagung. } \\
\text { Produk ice cream jagung } \\
\text { Bersihkan jagung, lalu pipil } \\
\text { Blender jagung dengan air, } \\
\text { kemudian disaring } \\
\text { Campur air perasan jagung } \\
\text { dengan agar-agar, gula dan } \\
\text { santan } \\
\text { Masak hingga mendidih } \\
\text { Tuang pada cetakan dan tiriskan } \\
\text { Simpan dalam lemari pendingin } \\
\text { agar pudding dapat disajikan } \\
\text { lebih baik }\end{array}$ & \\
\hline 3 & $\begin{array}{l}\text { Dimensi } \\
\text { Pemasaran } \\
\text { Produksi }\end{array}$ & $\begin{array}{l}\text { Jenis /model pemasaran yang } \\
\text { dikembangkan }\end{array}$ & $\begin{array}{l}\text { Pemasaran dilakukan } \\
\text { dengan metode } \\
\text { konsinyasi atau di jual } \\
\text { mandiri pada rumah } \\
\text { warga masing-masing }\end{array}$ \\
\hline
\end{tabular}

\section{Kesimpulan dan Saran}

\section{Kesimpulan}

Kegiatan pengabdian
masyarakan dilakukan $\begin{array}{r}\text { dengan } \\ \text { pendekatan praktek langsung pembuatan }\end{array}$
produk berbasis jagung di salah satu
rumah warga yang berprofesi sebagai ibu
rumah tangga dengan status pekerjaan
suami adalah sebagai petani musiman
yang beralamatkan di Dusun
Kedungpring, RT 1/RW 1 Desa Latsari,
Kecamatan Mojowarno, Kabupaten

Jombang. Pemilihan dusun didasarkan atas kondisi yang telah dibahas sebelumnya pada analisis situasi dan permalahan mitra dimana kehidupan masyarakat disana bergantung kepada hasil pertanian jagung namun belum adanya diversifikasi pangan sehingga ketika terjadi lag waktu masa tanam dengan masa panen, masyarakat tersebut tidak memiliki penghasilan tetap.

Sebagai upaya untuk penguatan ketahanan pangan yang dalam terapannya diperlukan ketersediaan pangan, akses terhadap pangan dan 
penghasilan, pemanfaatan atau penyerapan pangan, serta kerentanan pangan. Faktor akses terhadap pangan dan penghasilan perlu dikedepankan untuk menaikkan daya beli masyarakat desa melalui wirausaha pembuatan produk pangan olahan jagung. Profil mitra terpilih dengan mata pencaharian petani musiman diharapkan mampu memahami pengetahuan didalam pembuatan produk pengolahan jagung yang berdampak kepada multi income atau peningkatan pendapatan keluarga.

Diversifikasi kemampuan atau skill dalam bidang pengolahan pangan menjadi kebutuhan penting dan strategis sebagai upaya pemenuhan kebutuhan keseharian atas pangan yang bergizi serta memanfaatkan lebih banyak ketersediaan sumber lokal, sebagai misal produk olahan pangan berbasis jagung menjadi makanan khas masyarakat (Suarni et al., 2019). Demikian pula dengan pemenuhan pangan untuk warga masyarakat desa diperlukan kepandaian dalam pengolahan pangan untuk pemenuhan gizi standar serta diversifikasi ketersediaan pangan dan sekaligus wahana untuk pengembangan wira usaha. Pengolahan lebih lanjut bahan dasar pangan dari produk jagung tersebut menjadi berbagai macam jenis olahan pangan yang tentunya akan meningkatkan dan membangun selera makan serta kandungan gizi yang meningkat dan mampu dikembangkan lebih lanjut sebagai kegiatan berwirausaha dalam meningkatkan perolehan pendapatan sebagai sumber alternatif pengembangan kelembagaan lebih lanjut. Diantara sejumlah produk olahan berbasis jagung, diantaranya yaitu produk pudding jagung dan ice cream jagung.

\section{Saran}

Pemantapan pangan dan peningkatan pemenuhan gizi menjadi langkah strategis, keaneka ragaman pangan diharapkan mampu untuk menunjang program diversifikasi pangan, khususnya kebutuhan pangan masyarakat pedesaan. Produk pangan berbasis "jagung" untuk memenuhi variasi kebutuhan masyarakat desa, boleh jadi menjadi produk pangan utama di pedesaan. Khusus untuk warga pedesaan dimana tempe dan Tahu menjadi menu utama dalam hidangan pangan sehari-hari masyarakat pedesaan, sehingga jagung menjadi produk subtitusi dan pelengkap. Oleh karena itu, keanekaragaman pangan berbasis produk "Jagung" memiliki nilai keutamaan, salah satu alternatif mengembangkan sumber wirausaha. Disisi yang lain, upaya diversifikasi pangan dan peningkatan gizi sekaligus dapat digunakan sebagai media untuk meningkatan tingkat penghasilan. Maka diharapkan kedepan kegiatan berwirausaha akan terus berjalan kedepanya karena sebagian besar mata pencaharian mengandalkan pada pertanian yang dimana ditandai dengan tenggang waktu antara tanam dan panen, maka ada waktu luang tersebut yang akan menjadi berdaya guna bila digunakan untuk aktifitas produktif (berwirausaha).

\section{DAFTAR PUSTAKA}

Fitrianingrum, F., \& Aulia, B. U. J. J. T. I. (2018). Penentuan Lokasi Agroindustri Berbasis Komoditas Jagung di Kabupaten Jombang. 7(2), 100-106.

Krisnamurthi, B. J. P. P. S. N. (2010). Manfaat Jagung dan Peran Produk Bioteknologi Serealia dalam Menghadapi Krisis Pangan, Pakan dan Energi di Indonesia.

Suarni, S., Balai Penelitian Tanaman Serealia, M., Yasin, M., \& Balai Penelitian Tanaman Serealia, M. (2019). Jagung sebagai sumber pangan fungsional. 